\title{
During Most Recent Visit
}

National Cancer Institute

\section{Source}

National Cancer Institute. During Most Recent Visit. NCI Thesaurus. Code C148465.

Happening during a patient's most recent visit. 